\title{
ESCALATOR CLAUSES IN PUBLIC UTILITY RATE SCHEDULES
}

\section{R. S. Trigs $\dagger$}

One of the major problems in public utility regulation is the reconciliation of fixed rates to the pressures and demands of a fluctuating economy. Failure to make such a reconciliation results in unreasonably high rates in periods of economic recession, and hardship to the utility (in a few cases threatening discontinuance of service) during inflationary cycles. These effects are the twin offspring of the inevitable lag between general price changes and regulatory approval of changes in utility rates. The simplest and most widespread solution of the problem is the use of automatic rate adjustments, whereby the rates are allowed to vary automatically with changes in operating costs, prices of basic raw materials, or independently-published price indices.

This type of rate adjustment apparently originated during the first world war. ${ }^{1}$ The first cases in which such provisions were considered by state regulatory agencies were decided in 1917.2 The Pennsylvania Public Service Commission referred to them as unusual in $1918{ }^{3}$ and the Massachusetts Department of Public Utilities ruled that it would not during wartime sanction such a complete departure from prior practice. ${ }^{4}$ In spite of such administrative conservatism, the plan spread. By the middle 1920's it was a recognized and widely accepted method of utility rate-making, and the spate of administrative proceedings involving addition of such clauses to existing rate structures showed a marked decline. The Public Utility Reports series included only two or three decisions on the subject in the period 1924-1932, and only two between 1933 and 1940.

One of the latter two decisions marked a new departure. In the first decade of automatic rate revision, the basis for all such rate changes was variation in the price of fuel. This was and is the primary expense item for electric utilities. It was the logical choice for the

$\dagger$ Member, Philadelphia and Pennsylvania Bars; LL.B., University of Pennsylvania, 1951.

1. Uniform Fuel Clauses for Electric Companies, MASS. DFP'T of PuB. UTIL. No. 7357 (1946).

2. Alton Gas \& Elec. Co., 1917F P.U.R. 12 (II1.).

3. Mercer County Light, Heat \& Power Co., 1919A P.U.R. 907.

4. Plymouth Gaslight Co., 1919A P.U.R. 339 (1918). For the history of such clauses in California, see Pacific Gas \& Elec. Co., 82 P.U.R. (n.s.) 473, 488 (1949). 
bellwether for the additional reasons that it rose in price quite rapidly during the war period and its price was not subject to control by the utilities. In 1933 another type of expense showed signs of rapid increase as the New Deal presaged new and increased taxes. One utility sought to shift this burden to its customers by an automatic rate adjustment clause, but the regulatory agency disapproved.

"While the constantly increasing burden of taxation upon public utility service must necessarily be handed on to the user of public utility service, the Commission is of the belief that the amount of such burden in comparison with the other costs of furnishing utility service has not yet increased to such an extent as to justify the imposition of a clause in the rate schedule which automatically shifts this burden to the consumer. . . ." 5

The second world war, with its swift inflationary spiral, again brought automatic rates to the fore, although it must not be inferred that they had disappeared from rate structures between the two wars. In the past fifteen years, they have been shown to be an effective means of easing the regulatory burden without lifting any measure of regulatory control, and they have been extended to a broader basis, covering fuel prices, and in certain cases other expenses. Refinements have also been introduced to make them more sensitive to changed conditions both within the utility and in the economy as a whole. ${ }^{6}$

Today utility rates in almost every state can and do fluctuate from month to month, with no fanfare and frequently no litigation. If this is not contrary to the regulatory statutes, it certainly is not what was anticipated by the draftsmen of those statutes. In view of this, it would be logical to expect that the legal issues involved should have been thoroughly debated as the variable rates became more and more familiar. What development of legal concepts could affect more individual pocketbooks? Yet the fact is that the legal and practical problems involved in escalation of utility rates have received so little public attention that their logical ultimate development remains unrecognized, unutilized, and virtually unimagined.

\section{Purposes of Escalator Clauses}

In their inception, fuel clauses were designed solely to protect the utility's rate of return during an inflationary period; even the correla-

5. Newport Water Corp., 1933E P.U.R. 1, 25 (R.I.).

6. Since the early clauses were all concerned with fuel prices, this type of rate adjustment came to be known as a "fuel clause"; with the general adoption of similar provisions for increased tax burdens the term "tax adjustment" was adopted. Occasionally in the decided cases, and frequently herein, the term "escalator clause" is used to refer to both types, and also to include the clauses which are based on factors other than fuel or taxes. 
tive protection to the consumer in times of recession was probably mere window-dressing in order to make the effects of such a clause more palatable to the regulatory agencies. Later, the advantages of such a provision from a competitive viewpoint received some notice. This was particularly true in the adoption of the clauses by gas distributors, faced with competition by oil interests. The latter, being unregulated, could reduce prices quickly during slack seasons. In the struggle to retain customers who could easily switch to oil, the ability to meet reductions in oil prices as they occurred and thus maintain from month to month the competitive price relationship between the two fuels became of paramount importance. Accordingly, some gas utilities published schedules providing that gas rates would be adjusted in accordance with fluctuations in the price of oil. ${ }^{7}$

The same considerations affect, to a lesser extent, the rate structures of electric utilities as to customers in a position to construct their own generating plants; but since private generation of electricity is relatively uncommon, this type of escalator has not met with widespread approval. 8 In fact, the use of escalator clauses for competitive purposes by any type of utility has been openly sanctioned in only two states and Hawaii. ${ }^{9}$

The reluctance of the commissions to authorize this type of rate is clearly justified. The effect of such a rate is to allow increased charges because the customer is under economic duress, and reductions when forced by competition. At the time of the increase, no consideration is given to the utility's rate of return; nor to the relationship between rates to be increased and those to remain unchanged; nor, in fact, to the customers' ability (as distinguished from economic necessity) to pay. A regulatory commission which approves a rate of this kind is coming dangerously close to an abdication of its functions, and effecting indirectly a pro tanto repeal of the regulatory legislation.

The California Public Utilities Commission has devised one safeguard on such a rate. A reasonable rate is first established, after which fluctuation is allowed in order to maintain a prescribed relationship to competitive fuels. This fluctuation, however, may not be so applied as to result in a rate higher than the established reasonable level. The rate may decrease, and it may increase back to the original

7. See notes 79,80 infra.

8. Southern Cal. Edison Co., 6 P.U.R.3d 161, 205 (Cal. 1954).

9. Southern Counties Gas Co., 1 P.U.R.3d 475, 497 (Cal. 1953); Southern Cal. Gas Co., 87 P.U.R. (n.s.) 492, 514 (Cal. 1950); Wisconsin Pub. Serv. Corp., 65 P.U.R. (n.s.) 198, 201 (Wis. 1946) ; Wisconsin-Michigan Power Co., 76 P.U.R. (n.s.) 153 (Wis. 1948); Northern States Power Co., Wis. Pub. Serv. Comm'n No. 2-U-2781 (1948) ; Hawaiian Elec. Co., Hawaii Pub. Util. Comm'n No. 841, Exhibit A, Schedule $A$, at 2 (1955). For an unusual application of this principle, see Southern Cal. Gas Co., 1922A P.U.R. 536 (Ca1. 1921). 
level, thus compensating for prior decreases; but further increases are not permitted. ${ }^{10}$ This alleviates, but does not completely cure, the ills mentioned above which a competitive escalation involves.

The primary purpose of escalator clauses, as stated, is to protect the utility's rate of return during inflationary periods. At such times, the normal procedures involved in rate increases are unsatisfactory, involving as they inevitably do delays of months or even years. The point was admirably demonstrated before the Virginia State Corporation Commission, when escalator clauses were proposed by seven gas utilities, all of which purchased natural gas from the same source. Commissioner Catterall said in that case:

"When prices are rising, the time that necessarily elapses between the date when earnings fall below the permissible minimum rate of return and the date when the commission enters its order allowing increased rates, is a time during which the utility earns less than a fair and reasonable return. . . .

"The inevitable delay between the happening of an event that entitles a party to legal relief and the date when he gets relief makes it impossible in some kinds of cases for law and equity to do complete justice. Ever since Hamlet mentioned 'the law's delay' as one of the things that made him wonder whether it was better 'to be or not to be,' lawyers and legislators have sought ways of overcoming so far as possible the time lag in the machinery of justice. One purpose of the fuel clause in electric rate schedules and the escalator clause in natural gas rate schedules is to keep the mere lapse of time from operating in favor of or against either the stockholders or the consumers. The time factor is especially prominent in the cases before us because, since all seven distribution companies receive their gas through the pipelines of the same transmission company, all seven would start paying the changed purchase price on the same day. In the absence of an escalator clause, each of the seven companies would, if the increase were substantial, file new schedules. In order to hold hearings on the proposed increases in rates, the commission's staff would have to examine the books and records of seven companies. One company might get relief in two months and another company might not get relief for ten months. The company whose case was heard last would suffer unjustly compared to the companies whose cases were heard earlier, and it would be physically impossible to avoid that injustice. If there should be a substantial decrease in the wholesale price, the customers of the seventh company would suffer the largest injustice. There is no rule of law or justice for determining which of the seven applications should be investigated and heard first or last. The denial of the 
present applications might create a situation in which it would be physically impossible for the commission to render equal justice to all parties, because to public utility rate cases the maxim 'justice delayed is justice denied' is particularly applicable." 11

\section{Contentrons Pro and Con}

The objections which greeted the first escalation proposals have been heard and answered, and rejected by some state legislatures as well as the vast majority of regulatory commissions. ${ }^{12}$ Yet the objections are still heard, and are occasionally still upheld..$^{13}$

Aside from the universal desire to pay as little as possible for any service, the principal economic objection to escalation is its effect on the consumer's pricing policies. Where an article is offered for sale at a fixed price, computed on the known costs of production, a frequent fluctuation in production costs may throw the entire cost-price relationship off balance. In such a situation, a manufacturer may find himself operating at a loss because of unexpected, and in some cases retroactive, increases in utility charges.

The objection, however, is more theoretical than real. It may have some validity at the time the utility first adopts an escalator clause; but a slight revision of the utility consumer's pricing policy will normally prevent any further hardship. The best example of such a revision is the case of the Lynchburg Gas Company. When its primary supplier, also a utility, adopted an escalator clause, Lynchburg quickly did the same thing, thus protecting itself from any future loss. ${ }^{14} \mathrm{~A}$ manufacturer, it should be remembered, can alter prices much more readily than a utility, because the utility faces the necessity of obtaining prior governmental approval. It might also be noted that fluctuation in production costs is becoming increasingly common in our economy, as exemplified by long-term wage agreements providing for adjustments based on various commodity price indices. Perhaps this helps to explain why this particular argument, which defeated some escalator

11. Lynchburg Gas Co., 6 P.U.R.3d 33, 35-36 (Va. 1954), additional opinion sub nom. Virginia Elec. \& Power Co., 7 P.U.R.3d 108 (Va. 1954), aff'd sub nom. Norfolk v. Virginia Elec. \& Power Co., 197 Va. 505, 90 S.E.2d 140 (1955).

12. For legislation specifically authorizing escalation, see, e.g., Aruz. REv. Stat. ANN. \& 40-368 (1956); N.Y. PUb. SERv. LAW \& 65(4); OHIo REV. CODE ANN. § 4905.31 (Anderson 1953).

13. Portland Gas Light Co., 69 P.U.R. (n.s.) 154 (Me. 1947) ; Southern Utah Power Co., 93 P.U.R. (n.s.) 325 (Utah 1952) ; Montana-Dakota Util. Co., 13 P.U.R.3d 523 (Wyo. 1956). The Massachusetts Department of Public Utilities even while approving an escalation proposal expressed itself as "generally reluctant" to do so. Worcester Gas Light Co., 9 P.U.R.3d 152, 155 (1955).

14. See note 11 supra. 
proposals in the first decade of their development, ${ }^{15}$ has not received significant attention in the opinions of the past twenty years.

Further objection is raised that if a utility can automatically increase its rates when its costs rise, the utility loses the incentive to make reductions in costs, which reductions would eventually benefit the consumer. ${ }^{18}$ This argument contains just enough truth to sound convincing; actually it is so oversimplified as to be almost totally erroneous. To begin with, many escalator clauses, particularly those based on fuel costs, apply only to certain classes of customers (either industrial, or industrial and commercial, or all but the class paying the highest rate for the initial block of energy). ${ }^{17}$ There is usually also a moderate lag between the time the utility pays the increased cost and the reflection of that cost in billing. Furthermore, an escalator formula may be so constructed as to pass on to the consumers somewhat less than the full increase paid by the utility. All these factors mean that the utility must still bear some part of the increase. Even if that were not true, there are other incentives to economy. Rare indeed is the enterprise-even among public utilities-without some form of competition limiting its ability to ignore costs; and the improvident utility management is also subject to censure or stronger remedies administered by governmental regulators.

The purely legal objections to escalation fall into two groups. The first is based on the regulatory process itself; the second arises from the almost universal requirement of published tariffs.

The first group involves three logically separate contentions, which are almost invariably so intertwined in the agency opinions that their separation for analysis is quite difficult if not, at times, impossible. Of these, the most sweeping is that approval of escalator clauses prevents subsequent supervision of the utility rates or rate structure. The California Public Utilities Commission gave voice to this argument in Southern Cal. Gas Co.:

"In the past the automatic action of the present form of fuel escalator clause in the interruptible rate has virtually taken out of the Commission's hands the control of the level of the rate. At times it has appeared to the Commission that an automatic change in the price of gas when the price of oil changed was not warranted." 18

To alleviate this situation the Commission required that fuel clauses published thereafter should expressly show that the escalation would

15. Union Elec. Light \& Power Co., 1918E P.U.R. 490, 509 (Mo.) ; H.J.M. Jones, 1921D P.U.R. 145, 150 (Vt.).

16. Utah Power \& Light Co., 95 P.U.R. (n.s.) 390, 399 (Utah 1952).

17. Union Elec. Light \& Power Co., 1918E P.U.R. 490, 508 (Mo.).

18. 99 P.U.R. (n.s.) 272, 287 (1952). 
be subject "to any revisory action that may be deemed necessary in the public interest by the California Public Utilities Commission in the exercise of its jurisdiction pursuant to the provisions of law and the rules and regulation's of said Commission." 19

The Maine Public Utilities Commission is even more conservative, fearing that if it approved of escalation "we doubt that we should be properly discharging our public duty. . . . [Escalation] calls for a delegation of the public responsibility of this Commission to the utility. Although it is permissive in character and subject to recall, it is nevertheless effective." 20 The last sentence quoted is a close paraphrase of the position taken by the Illinois Public Utilities Commission in an early case, ${ }^{21}$ but oddly enough the latter Commission had approved an escalator clause only a month previously. ${ }^{22}$

The California Commission's action outlined above is in itself a sufficient answer to this argument. Massachusetts has provided another answer, by suspending increases announced by the utility pursuant to a previously-approved escalator clause. ${ }^{23}$ And the Virginia Supreme Court of Appeals gave still a third, pointing out that any person who believed the rates as increased by escalation to be unreasonable could file a complaint with the Commission. ${ }^{24}$ Escalation, in short, has no effect on the powers of the regulatory agency; it is a remedial measure only, designed to prevent in part the evils resulting from the delays inherent in the administrative process.

The next of this group of objections, in order of frequency of assertion, is that escalator clauses permit rates to be increased, above what had been previously accepted as a reasonable level, without consideration of all factors which should be examined in determining the reasonableness of a rate. For example, the Massachusetts Department of Public Utilities, even while approving a fuel clause, warned that "increases in cost generally must be studied, not as an individual item but as a portion of the over-all costs of the utility incurred in doing business." ${ }^{25}$ The Maine Public Utilities Commission, although prohibited by the state's Supreme Judicial Court from approving any escalator clause, ${ }^{26}$ volunteered the opinion that in approving any rate

19. Ibid.

20. Portland Gas Light Co., 69 P.U.R. (n.s.) 154, 157 (1947).

21. Rockford Elec. Co., 1917F P.U.R. 196.

22. Alton Gas \& Elec. Co., 1917 F P.U.R. 12. See also Public Serv. Co., 1924B P.U.R. 386 (Ill. 1924).

23. Worcester Light Co., 9 P.U.R.3d 152 (1955). The opinion even leaves some doubt whether a tariff supplement or merely a letter of notice had been filed.

24. Norfolk v. Virginia Elec. \& Power Co., 197 Va. 505, 518, 90 S.E.2d 140, 149 (1955).

25. Worcester Gas Light Co., 9 P.U.R.3d 152, 155 (1955).

26. Or so the Commission interpreted In re Caribou Water, Light \& Power Co., 121 Me. 426, 117 Atl. 579 (1922). 
increase all factors entering into rate-making should be considered, since while fuel costs are increasing other costs might decrease and thus result in a net decline in the utility's operating costs. ${ }^{27}$

This argument is valid only in exceptional economic circumstances. Generally speaking, prices fluctuate similarly to other prices. Whether the general trend is inflationary or recessive, all prices tend to move in the same direction. There are exceptions, of course; but these normally involve commodities or services either relatively new or approaching obsolescence, whose position in the economy is unfixed. A recent example is the price of television sets during the middle 1940's. But the supposition that one major cost factor will fluctuate in direct opposition to the current norm is unrealistic, and the agencies which have allowed this possibility to frighten them are either economically naive or are adopting a specious rationale to cloak the real reasons for their decisions.

Concededly there may be occasions when a given escalator formula will overcompensate for the experienced cost increases, where the increases in costs made part of the formula are proportionately greater than other increases incurred by the utility. But the overcompensation will in all probability be less than the opposite effect which results from rigid rate structures, since the utility is overcompensated only to the extent that its other costs rise at a slower rate than its accelerated costs, while, when there is no escalation, the utility is undercompensated by the sum of all price rises. And in such cases there is always a remedy available-either regulatory suspension of the rate changes resulting from escalation at a given time, or complaint by a consumer as to the reasonableness of the resulting rates.

The third objection in this group perhaps stems from these very remedies. It is said that the effect of escalation is to shift the burden of proving the reasonableness or unreasonableness of particular rates "from the utility where it legally belongs, to the Commission where it does not belong," ${ }^{28}$ or to the consumer. This is the easiest of the arguments to answer. The Natural Gas Act provides that "at any hearing involving a rate or charge sought to be increased, the burden of proof to show that the increased rate or charge is just and reasonable shall be upon the natural-gas company. . . ." 29 The Federal Power Act contains identical language, except that "public utility" is substituted for "natural-gas company." 30 Virtually all the state regulatory

27. Portland Gas Light Co., 69 P.U.R. (n.s.) 154, 157 (Me. 1947).

28. Ibid.; see also Rockford Elec. Co., 1917F P.U.R. 196 (II1.); Georgia Power Co., Ga. Pub. Serv. Comm'n No. 466-U, at 3 (March 23, 1953).

29. 52 STAT. 822 (1938), 15 U.S.C. \& 717c(e) (1952).

30. 49 STAT. 852 (1935), 16 U.S.C. \$ 824d(e) (1952). 
acts have similar if not identical provisions. Thus, upon filing of an automatic rate increase, if the Commission doubts that the resulting rates would be just and reasonable, it may suspend the rates. In any further proceeding on the propriety of such increases, the burden of proof to show that such rates will be just and reasonable shall be upon the proponent utility. Considerations with regard to burden of proof in instances where rates are increased by operation of an escalator clause are, therefore, the same as they are in instances where the rate is increased by the filing of a new tariff; and the position of the parties with respect to burden of proof is likewise the same in each situation. Again, the administrative agencies which adopt such arguments are using them to cloak the real reasons for their decisions.

These legal objections are frequently confused in the decisions, to such an extent that they often appear as only one argument. The remaining contention is always separately stated, since it bears less on the political-philosophical and more on the practical aspects of the arrangement. It involves the principle that public utility rates should be published and definite. This may be divided, for purposes of analysis, into two parts: the stability of the rates, and the method of publication of those rates. The latter problem is significant enough to warrant separate treatment; only the issue of stability will be discussed at this point.

The Illinois authorities were among the first to espouse the stability of rates:

"The supplement herein proposed contemplates that the rates for service shall not be determined until the end of the month in which the service is rendered, and that these rates will be affected by the cost of coal during that month. . . . [I]t is apparent that the Commission would not be in a position to determine from the schedule as filed what the present charges for service furnished or to be furnished . . . are, since it would have no definite knowledge of what the price of coal was to be during the month in consideration, even though that month might be the current month." 31

Numerous commissions were concerned as to the consumers' ability to understand the rates charged under escalator clauses. In the early days of escalation, the New Jersey Board of Public Utility Commissioners refused to approve a clause based on the price of gas oil for this reason, ${ }^{32}$ although they had previously permitted a coal clause which applied only to large industrial users who could understand the

31. Rockford Elec. Co., 1917F P.U.R. 196, 199.

32. Public Serv. Gas Co., 1920E P.U.R. 396. 
principle involved. ${ }^{33}$ New York's Public Service Commission reached the same conclusion.

"Applied to . $\therefore$. large consumers, with officials having the information and experience necessary to calculate their expenses with this clause in view, such rates have not been the subject of complaint, and it must be assumed that they have operated equitably and to the satisfaction of the electrical corporations and the consumers as well. Whether they should be applied to the great mass of consumers may not present a different legal question, but certainly presents an entirely different problem as to justice and expediency. . . . While the result might not be unjust to the permanent consumer . . ., the very uncertainty would be bound to cause discontent and suspicion." ${ }^{34}$

In recent years this argument has met with decreasing success. ${ }^{35}$ It was followed in Georgia in $1948,{ }^{36}$ but the New York and Utah commissions have recognized the problem and nonetheless approved escalator clauses applicable to all classes of consumers. ${ }^{37}$ In fact, after almost forty years' experience in its operation, it can be said that escalation has proved successful, and has not borne out the dire predictions of its foes.

Today, the vast majority of electric utilities use fuel clauses. ${ }^{38}$ Such clauses have been incorporated in retail electric rate tariffs in forty-four states; tax adjustment clauses have been adopted in thirtyfour, including the four where fuel clauses are not extant (although in many of these thirty-four states no charges have been imposed under the tax clauses). In seven states where electric utilities are subject to state regulation, and in two where such regulation is not imposed, escalator clauses have appeared which are based on changes in costs other than fuel and taxes. ${ }^{39}$ Interestingly enough, the four states where no fuel clauses have been adopted are Idaho, Montana, Oregon, and Washington-an area where hydroelectric generation would necessarily enter any computation of fuel clauses, and probably into the competitive considerations preceding a utility's decision to propose them; no decision of any of these jurisdictions has been found rejecting a fuel clause. Conversely, fuel clauses are included in the

33. Atlantic County Elec. Co., 1918B P.U.R. 589, 592.

34. Rochester Gas \& Elec. Corp., 1921A P.U.R. 415, 417-18.

35. See text at notes 43-46 infra.

36. Georgia Power \& Light Co., 74 P.U.R. (n.s.) 69, 78.

37. New York Edison Co., 10 P.U.R. (n.s.) 244, 260-62 (N.Y. 1935) ; Southern Utah Power Co., 77 P.U.R. (n.s.) 109 (Utah 1949).

38. See Duke Power Co., 75 P.U.R. (n.s.) 33 (N.C. 1948): "[A]nalysis of 100 of the largest power companies in the country shows that 86 have fuel clauses."

39. Retail rate schedules shown in FPC, NATIONAL ELECTrIC RATE Book (1956). Jurisdiction of regulatory agencies based on MOODY, PUBLIC UTIIIIIES (1955). 
tariffs of two large electric utilities in Maine, notwithstanding their condemnation by both court and commission. ${ }^{40}$ Each of the jurisdictions whose objections to escalation are quoted or cited herein has approved of the method in some form. ${ }^{41}$

\section{Types of Fuel Claudes}

Examination of fuel clauses presently included in retail electric rate schedules establishes a great variety of factors entering into their application. ${ }^{42}$ Such clauses are so varied that rarely, if ever, can any generalizations be made concerning any particular factor.

This may best be shown with reference to the classes of consumers whose rates may be escalated. The early clauses applied only to large consumers, apparently at the request of the utilities, who feared that the cost of billing residential consumers for the additional charges would be more than the resulting revenue. ${ }^{43}$ This factor is still given considerable weight, ${ }^{44}$ but it is not as controlling as it once was, perhaps because of the increased efficiency of billing operations mechanically performed. In several more recent cases utilities have requested extension of existing clauses to smaller customers, ${ }^{45}$ and such requests are frequently approved in order to remove the stigma of discrimination against large users of utility service. ${ }^{46}$

There are other aspects of this problem of discrimination which merit attention. It has been said, for example, that escalation of industrial rates without similar escalation of residential rates is not discriminatory, inasmuch as the industrial user is still paying only the increased cost of fuel burned in generating electricity used by him-he is not asked to contribute to the increased cost attributable to residential use. ${ }^{47}$ The utility absorbs the latter portion of the cost increases, rather than incur the expense of billing small surcharges. This is not completely true, however, since as the utility absorbs the increase in cost,

40. In re Caribou Water, Light \& Power Co., 121 Me. 426, 117 Atl. 579 (1922); Portland Gas Light Co., 69 P.U.R. (n.s.) 154 (Me. 1947).

41. Except possibly Rhode Island, as to which no favorable decision has been found although both fuel and tax clauses are known to be extant within the state.

42. The statistics in this section are compiled from examination of FPC, NAtronar. ELECTRIC RATE BOOK (1956). Where unusual features are mentioned, reference to the particular schedule is by state, utility company, and Rate Book schedule number. The schedule numbers relate to the Rate Book as published during 1956, and may vary in subsequent additions.

43. Union Elec. Light and Power Co., 1918E P.U.R. 490, 507 (Mo.).

44. New York Edison Co., 10 P.U.R. (n.s) 244, 260 (N.Y. 1935).

45. New Haven Gas Light Co., 70 P.U.R. (n.s.) 187 (Conn. 1947); Springfield Gas Light Co., 70 P.U.R. (n.s.) 82 (Mass. 1947).

46. Ibid; Hartford Elec. Light Co. 95 P.U.R. (n.s.) 161, 176 (Conn. 1952). Contra, New York Edison Co., 10 P.U.R. (n.s.) 244, 260 (N.Y. 1935).

47. Union Elec. Light \& Power Co., 1918E P.U.R. 490, 507 (Mo.). 
for fuel allocated to small consumers, it necessarily enlarges the proportional contribution of industrial customers to its overall rate of return. Thus, although escalation applied only to a limited class in this manner is prima facie not discriminatory, to the extent that the utility must pass along the absorbed cost increases to the industrial consumer it tends to become discriminatory.

"When rates have been fixed for all classes of service with due consideration for equitable relationship between classes, such relationship cannot be maintained if one class be required to bear the entire burden of an increase in cost which affects the service of all classes." 48

Even so, the discrimination is not ipso facto unreasonable. Large power consumers universally pay less per unit of power than do small consumers; thus (assuming that the same amount of fuel is required to produce a given unit of power regardless of the eventual user of that unit) the proportion of the rate attributable to fuel costs is much greater for the large customer than for the small. ${ }^{49}$ The classification, then, and the escalation of some but not all rates, is not necessarily unreasonable. ${ }^{50}$

In some cases the determination to exempt residential customers from escalator increases is based on facts completely unique to the individual utility. For example, the New Mexico Public Service Commission, while approving such a clause for application to industrial users, refused to allow it as applied to commercial and residential service, on the ground that the rates in these schedules were already higher than rates for comparable service in surrounding areas. ${ }^{61}$

Again, the decision to exempt residential service, particularly if made by the Commission contrary to the request of the utility, may be - based on the lesser ability of the residential customer to understand a month-to-month variation in the rate at which he is billed. ${ }^{62}$

Thus the battle rages. The reported decisions would appear to indicate that only a minority of regulatory bodies permit escalation as applied to residential service; but this appearance is somewhat exag1945)

48. Consolidated Gas, Elec. Light \& Power Co., 61 P.U.R. (n.s.) 94, 103 (Md.

49. Because of this, one case held a fuel clause applicable to all classes of consumers was a discrimination against residential consumers. Bridgeton Elec. Co., $1917 \mathrm{~F}$ P.U.R. 205 (N.J. 1917).

50. Detroit Edison Co., 78 P.U.R. (n.s.) 360, 378 (Mich. 1949); Union Elec. Light \& Power Co., 1918E P.U.R. 490, 507 (Mo.).

51. Community Pub. Serv. Co., 93 P.U.R. (n.s.) 18 (1951).

52. Georgia Power \& Light Co., 74 P.U.R. (n.s.) 69, 78 (Ga. 1948) ; Public Serv. Gas Co., 1920E P.U.R. 396 (N.J.); cf. Southern Utah Power Co., 77 P.U.R. (n.s.) 109 (Utah 1949) and cases cited notes 32-34 supra. 
gerated, apparently by the selection of opinions to be published. Actually fuel clauses applicable to residential users exist in seventeen of the thirty-eight states exercising regulatory jurisdiction over electric utility rates and allowing fuel clauses in any form. Each of the seventeen, incidentally, has other fuel clauses which are not applicable to residential service.

Another factor in fuel clauses as to which significant variations appear both within and among the jurisdictions is that relating to experience. This factor is closely related to the original purpose for fuel clauses. Elimination of the administrative time lag would be of but little advantage if the method of elimination embodied an equivalent lag of its own. Yet virtually all of the fuel clauses presently in use contain a built-in time lag, ranging from a month to a year or more. (The vast majority of tax clauses, on the other hand, are so drafted as to eliminate this delay.)

The justifications for such a factor do not appear in the opinions, but they are easily imagined. To begin with, the prevalence of an experience period of a year must be based in part on seasonal fluctuations in efficiency or fuel prices or both, which may be taken into consideration in order to avoid excessive fluctuation in rates. In the second place, the varying efficiency of production units makes it necessary to use average costs, and a period of time is essential to determination of the average. ${ }^{53}$ Thus the minimum lag is designed to allow for collection of data on which the adjustment is based, calculation of the exact rate of adjustment, and notice to consumers and commissions. Thirdly, in some cases the regulatory agencies require that no change be effected until a succeeding billing period, on the theory that a utility may charge a higher rate only for service rendered after notice of the rate increase is given to the public.

The first two explanations, it will be noted, are practical rather than legal, and therefore probably stem as much from utility preference as from commission imposition. The third, being a legal principle, may arise from either source. But the surprising aspect of this experience factor problem is not the source of the provision; it is the complete lack of uniformity, or even of any recognizable pattern.

It has previously been pointed out that every jurisdiction which allows fuel clauses to be applied in residential service also allows such clauses which are not so applied. Similar statements can be made with reference to experience factors. Of the forty-eight states six have no regulation of electric utility rates; in four others no fuel clauses are

53. Propriety of Fuel Clauses, Mass. Dep't of Pub. UTI. No. 7357 (1946). 
presently applicable. In at least thirty-three of the remaining thirtyeight states, more than one experience factor is presently in use in computing fuel adjustments. ${ }^{54}$

The variety of experience factors in use in a few states will serve to emphasize the lack of uniformity. For example, Pennsylvania utilities use the average cost of power over a three-month period, ${ }^{65}$ or during the second month preceding the billing month, ${ }^{56}$ or the calendar month immediately preceding the billing month, ${ }^{57}$ or during the preceding calendar year. ${ }^{58}$ In Missouri, it may be the preceding month, ${ }^{69}$ or twelve months, ${ }^{60}$ or three months, ${ }^{61}$ or the preceding month with provision for deferred billing; ${ }^{62}$ or the experience factor may not appear in the rate schedule. ${ }^{63}$ Illinois companies use the average for twelve months ending with the second month preceding the billing month, ${ }^{64}$ or the six months ending at the same time, ${ }^{65}$ or the earliest three of the next prior five months, ${ }^{66}$ or two calendar months immediately preceding the billing period, ${ }^{87}$ or the preceding month. ${ }^{88}$ Connecticut schedules include the average price of "fuel burned in the month," ${ }^{69}$ and the average for a calendar quarter, ${ }^{70}$ and for the second preceding month, ${ }^{71}$ and for no stated length of time. ${ }^{72}$ The variations in use in Connecticut are particularly interesting. In 1944 the state's Public Utilities Commission proposed a uniform fuel clause, embracing a five-year average price of fuel; in the ensuing investigation, the utilities objected to this and proposed a one-year basis. The Commission accepted this modification in its decision, but neglected to mention any experience factor in the order $;^{73}$ and apparently the omission has resulted in Connecticut

54. In two other states more than one experience factor may be in use, but the factor is not indicated in FPC, NATIONAL ELECTRIC RATE BOOK, and correspondence with the utility has failed to establish sufficient information to determine whether differing factors are applied.

55. Pa., Philadelphia Elec. Co., 93.

56. Pa., Cumberland Valley Elec. Co., 21.

57. $\mathrm{Pa}$, Borough of Chambersburg, 166 .

58. Pa., Grove City Municipal Elec. Plant, 184.

59. Mo., Arkansas-Missouri Power Co., 7.

60. Mo., Kansas City Power \& Light Co., 42.

61. Mo., Missouri Pub. Serv. Co., 117.

62. Mo., Empire Dist. Elec. Co., 32.

63. Mo., Jackson Water \& Light Dep't, 278.

64. Ill., Central IIl. Elec. \& Gas Co., 1.

65. I11., Central I11. Light Co., 18.

66. I11., Central I11. Pub. Serv. Co., 46.

67. I11., Illinois Power Co., 113.

68. III., Northwestern Ill. Gas \& Elec. Co., 160. In practice this has the same effect as the clause referred to at note 64 supra. Letter from E. M. Nicholson, Interstate Power Co., to author, Jan. 24, 1957.

69. Conn., Connecticut Light \& Power Co., 1.

70. Conn., Housatonic Pub. Serv. Co., 107.

71. Conn., Mystic Power Co., 126.

72. Conn., Connecticut Power Co., 13. 1944).

73. Uniform Fuel Clause for All Electric Companies, 54 P.U.R. (n.s.) 57 (Conn. 
being today in the forefront of those states whose rate schedules are least uniform as to this factor.

Certain types of experience provision merit further comment. The first is the type, referred to above as in use in Missouri and Connecticut, but not uncommon elsewhere, in which the experience factor is not stated. It may be implied, as in the following provision:

"The energy charge will be increased or decreased $0.015 \phi$ per kwh for each $20 \phi$, or major fraction thereof, increase or decrease in the weighted average cost of coal, delivered in the cars to the siding at the utility's generating stations above or below $\$ 4.50$ per net ton having a heating value of $12,750 \mathrm{Btu}$ per lb. 'dry.' " 74

Or the provision may be so worded as to be ambiguous, for example: "The energy charge will be increased $0.0012 \phi$ per kwh for each $1 \phi$ variation in the cost of coal delivered to utility above or below $\$ 3.70$ per net ton." 75 The latter clause may use "cost" to refer to average cost over an undefined period, but it could also be interpreted as a reference to spot price at the time the rate of adjustment is calculated.

There would be no question of the proper interpretation of the last-quoted provision, if all unambiguous fuel clauses contained an experience factor. In that event it would be presumed that an experience period would be used to determine "cost." But in some cases the clauses specifically refer to spot prices. One New York utility, for example, refers to the price of bituminous coal "at the utility's . . . generating station as of the 1st day of the month in which the billing cycle commences." 78 A clause in use in Vermont refers to delivered cost of fuel oil "for the preceding month or the last date of purchase whichever shall be the later." 77 In California the adjustment is determined by the price of oil "as regularly quoted by the Standard Oil Co. of California"; ${ }^{78}$ gas tariffs have a similar provision except that they are governed by the lowest quotation posted by any of three oil companies. ${ }^{79}$ The Hawaii Public Utilities Commission approved a clause stating that "the cost of fuel oil prevailing on the 15th day of the calendar month immediately preceding the month in which the bill is rendered shall be used in computing the amount of such adjustment." 80

74. Wis., Wisconsin Power \& Light Co., 78. (Emphasis added.)

75. Utah, Southern Utah Power Co., 7; see also Ariz., Arizona Pub. Serv. Co., 2.

76. N.Y., Central Hudson Gas \& Elec. Corp., 4.

77. Vt., Central Vt. Pub. Serv. Corp., 10.

78. Cal., California Elec. Power Co., 12.

79. See Southern Cal. Gas Co., Cal. Pub. Util. Comm'n No. 44741 (1950).

80. Hawaiian Elec. Co., Hawaii Pub. Util. Comm'n No. 841, Exhibit A, Schedule $A$, at 2 (1955). 
Thus experience factors, though almost universally accepted, are not essential to the operation of a fuel clause; they are merely a means of determining, more or less arbitrarily, ${ }^{81}$ the cost of fuel to the utility. They have been criticized as allowing future patrons to pay for the utility's past operating expenses, ${ }^{82}$ but this is to some extent probably unavoidable as long as rates may not be legally changed retroactively. ${ }^{83}$ However, in keeping with their primary purpose, the tendency is to permit reduction in the time involved. For example, the Arkansas Public Service Commission recently authorized an existing fuel clause to be changed substituting for a twelve-month average cost the average cost for the second preceding month. ${ }^{84}$

In view of the practical considerations involved, lack of uniformity might be expected in experience factors. By the same token, the practice with regard to prompt-payment discounts should logically be completely consistent. Fuel clauses are theoretically so constructed as to compensate for increased fuel costs, and no more; if a discount is allowed on this portion of the bill, the utility either obtains a windfall from each late-paying customer, or does not regain as much from the clause as it logically should. For this reason, most utilities provide that the fuel clause adjustment shall not be subject to any discount. ${ }^{85}$ But there are a few which disregard the logic of the matter, and allow a discount on the entire bill. ${ }^{86}$

The determination of the appropriate base price to be included in the clause merits more consideration than it has received in published opinions. This determination falls into two parts: the period of time to be used, and the proper price relationship existing during that period, which is adopted as the measure of escalation. Normally the period of time chosen is one which is both recent and representative-the latter requiring a period of relatively stable fuel prices. But the fact that the base period initially chosen is normally quite recent does not indicate any necessity for maintaining the formula on an up-to-date basis. Thus, one utility retained its original base price for two decades, without

81. Propriety of Fuel Clauses, Mass. Dep'T of Pub. UtiL. No. 7357 (1946). Glenns Falls Portland Cement Co. v. New York Power \& Light Corp., 69 P.U.R. (n.s.) 37 (N.Y. 1947).

82. Rochester Gas \& Elec. Corp., 1921A P.U.R. 415, 430 (N.Y.) (dissenting opinion).

83. Cf. Rockford Elec. Co., 1917F P.U.R. 196 (III.).

84. Arkansas Power \& Light Co., 13 P.U.R.3d 1, 20 (1956). This approach appears to be the best reconciliation of the conflicting factors which must be recognized in fixing an experience level, including the need to discount sudden or temporary cost changes, the desirability of maintaining the base for escalation on as nearly a current basis as possible, and the need to avoid the delays inherent in full administrative hearings prior to a change in the cost basis for the escalation.

85. E.g., Pa., Cumberland Valley Elec. Co., 21 .

86. E.g., Ohio, Marietta Elec. Co., 105. 
incurring regulatory displeasure. ${ }^{87}$ The base period should be changed, however, with sufficient frequency to account for substantial changes in system efficiency. ${ }^{88}$

Even these changes, however, may be avoided if the base price is stated in terms of a relationship which takes efficiency into account. In the case of electric rates, this can be done by using as a base the price per kilowatt hour, rather than the price per unit of fuel. Clauses using relationships other than price per ton of coal or gallon of oil have been criticized as increasing the difficulty of comprehension by the average consumer; ${ }^{89}$ but research does not disclose any case in which such a clause has been disapproved on that ground. Indeed, the tendency is in the opposite direction.

The simplest relationship on which to base fuel escalation is the price per unit of fuel. When generating stations were not readily convertible from one fuel to another, this was fairly satisfactory. A few fuel clauses are still constructed in this manner. ${ }^{90}$ In some cases retention of this system is necessary because the utility is charged on this basis by other utilities from which it purchases power. For example, Niagara Mohawk Power Corporation uses a price-per-ton basis; ${ }^{91}$ accordingly, New York State Electric and Gas Corporation uses the same basis in rate schedules for consumers whose needs are met with power purchased from Niagara Mohawk. ${ }^{92}$ But in areas where it generates its own power, New York State Electric and Gas Corporation has advanced to the use of clauses based on price per million BTU. ${ }^{93}$

The same result is often achieved by indirection by referring to the price "per short ton (containing 14,000 BTU per pound) in the average delivered cost of coal," "94 or by defining a ton of fuel as "a quantity of coal, or its equivalent, containing 29,000,000 BTU." 95 This calculation is some improvement. It permits the utility to use alternative fuels without upsetting the rate provisions, thereby taking into account the recent development of generating equipment capable of conversion from one fuel to another. ${ }^{96}$ But it is only an intermediate step, since it does

87. Wisconsin Pub. Serv. Corp., 65 P.U.R. (n.s.) 198, 201 (Wis. 1946) ; cf. Duquesne Light Co., $32 \mathrm{~Pa}$. Pub. Util. Comm'n 129, 179 (1954).

88. Propriety of Fuel Clauses, MAss. DEP'T of PUB UTn. No. 7357 (1946).

89. New York Edison Co., 10 P.U.R. (n.s.) 244, 260 (N.Y. 1935).

90. E.g., Pa., Pennsylvania Power Co., 69.

91. N.Y., Niagara Mohawk Power Corp., 87, 89.

92. N.Y., New York State Elec. \& Gas Corp., 67.

93. N.Y., New York State Elec. \& Gas Corp., 42, 45, 51.

94. Va., Eastern Shore Pub. Serv. Co., 15.

95. Conn. United Illuminating Co. 145. The ratio of BTU per pound may vary from 12,750 BTU (III., South Beloit Water, Gas \& Elec. Co., 184) to 16,240 BTU (R. I., Narragansett Elec. Co., 24, expressed as 32,480,000 BTU per ton).

96. Brooklyn Union Gas Co., 45 P.U.R. (n.s.) 54, 59 (N.Y. 1942); New York Edison Co., 10 P.U.R. (n.s.) 244, 260 (N.Y. 1935). 
not reflect increases in thermal efficiency of the generating system itself. To do that, the base relationship should be expressed in terms of price per kilowatt hour.

Of course, occasional revision of a price-per-BTU clause can keep it approximately abreast of improvements. ${ }^{97}$ But this method, while eliminating the administrative time lag as a burden on the utility, tends to overcompensate the company for cost increases, and therefore has met with official disapproval in some cases. ${ }^{98}$ Recent decisions of the Pennsylvania Public Utility Commission demonstrate the emphasis on base relationships which afford recognition to increased efficiency. In 1951, the Commission approved a fuel clause with a fixed efficiency factor-equivalent to a basis of price per BTU. ${ }^{99}$ Shortly thereafter it required revision of a fuel clause, and included in the amendments a factor based on the utility's efficiency experience-in effect, directing use of a price-per-kilowatt-hour basis. ${ }^{100}$ In 1953, it expressly directed adoption of a price-per-kilowatt-hour basis. ${ }^{101}$ Again in 1956 it disapproved a clause based on price per ton, directing that the clause be either withdrawn or revised to reflect cost per kilowatt hour..$^{102}$

In spite of such decisions, uniformity within the state is not to be expected in the near future. Some clauses cannot well be changed, inasmuch as they are correlated to those of other utilities. ${ }^{103}$ Even without this consideration, the utilities within the state currently use clauses variously based on cost per ton of coal, ${ }^{104}$ per million BTU, ${ }^{105}$ and per kilowatt hour. ${ }^{108}$

Two state commissions have attempted to obtain some measure of uniformity in fuel clauses, without notable success. The Connecticut proceeding has already been noted, together with its ineffectiveness concerning experience factors. ${ }^{107}$ With regard to base prices its lack

97. Wisconsin Pub. Serv. Co., 65 P.U.R. (n.s.) 198, 201, (Wis. 1946).

98. Cf. Duquesne Light Co., 32 Pa. Pub. Util. Comm'n 129, 182 (1953), rev'd on other grouthds, $176 \mathrm{~Pa}$ Super. 568 (1954).

99. Duquesne Light Co., $29 \mathrm{~Pa}$. Pub. Util. Comm'n 674, 766 (1951), aff'd sub nont. Pittsburgh v. Pennsylvania Pub. Util. Comm'n, 171 Pa. Super. 187 (1952).

100. United Ice \& Coal Co. v. Pennsylvania Power \& Light Co., 89 P.U.R. (n.s.) 432 (1951), rehearing denied, 30 Pa. Pub. Util. Comm'n 371 (1952), aff'd sub nom. Magee Carpet Co. v. Pennsylvania Pub. Util. Comm'n, 174 Pa. Super. 438 (1954).

101. Duquesne Light Co., $32 \mathrm{~Pa}$. Pub. Util. Comm'n 129, 182 (1953), rev'd on other grounds, $176 \mathrm{~Pa}$. Super. 568 (1954).

102. Metropolitan Edison Co., 13 P.U.R.3d 29, 85 (1956) (The utility withdrew the clause.).

103. Pa., Pennsylvania Elec. Co., 60. See text following note 90 supra. The ill effects of tampering with such a clause are shown in Boston Consol. Gas Co. v. Department of Pub. Util., 321 Mass. 259, 72 N.E.2d 543 (1947).

104. Pa., Pennsylvania Power Co., 69.

105. Pa., Philadelphia Elec. Co., 93.

106. Pa., Pennsylvania Power \& Light Co., 82.

107. See note 73 supra and text at notes $69-72$ supra. 
of success is equally notable. Notwithstanding the Commission's order that "the fuel adjustment clause shall provide that the cost of fuel shall be the price per net ton of coal, or its equivalent, . . ."108 the state's utilities now use fuel clauses based on cost per net ton of coal, ${ }^{109}$ per million BTU, ${ }^{110}$ and per kilowatt hour. ${ }^{111}$ Massachusetts has been more successful. Its investigation, unlike Connecticut's, was conducted after the war. Like Connecticut, it prescribed that the base cost be stated in cents per ton of fuel; but it went one step farther and defined a ton of fuel as that quantity, whether coal or oil, which contains 29,000,000 BTU. ${ }^{112}$ Today, virtually all Massachusetts utilities use this base price; of the two exceptions, one refers to a price per ton and thus may be in conformance with the uniformity order. ${ }^{113}$ The other adjustment is expressed in cents per gallon of oil. ${ }^{114}$

\section{Tax Clauses}

Tax clauses were first proposed some time after fuel clauses had been authorized by several if not the majority of the states. Being less imperative, they met with a less favorable initial reaction. The Missouri Public Service Commission could say with impunity that although a fuel clause was a virtual necessity it did "not believe that . . . the item of taxes will be subject to such sudden and radical changes that it cannot be provided for in the nature of a fixed charge per kilowatt hour." 115

One of the earliest tax clauses was a private arrangement between the utility and a municipal consumer, whereby the municipality agreed to pay for water service a certain sum plus any taxes imposed on the utility by the municipality. One suspects that the parties had desired a tax immunity which was contrary to law and devised this method of accomplishing the same purpose. If so, the outcome prevented the indirect achievement of that which could not be done directly; but this does not appear in the report. Although the Public Utilities Commission approved the contract, the Supreme Judicial Court ruled that the rate was unlawful. ${ }^{116}$ The court's opinion, unfortunately, is not a model of clarity. Indeed, it is difficult to determine whether the court thought it unreasonable that the town, as opposed to its residents,

108. Uniform Fuel Clause for All Electric Companies, 54 P.U.R. (n.s.) 57 (1944).

109. Conn., Connecticut Power Co., 13.

110. Conn., Connecticut Light \& Power Co., 1.

111. Conn., Mystic Power Co., 126.

112. Propriety of Fuel Clauses, MAss. Dep'T of PuB. UTnL. No. 7357 (1946).

113. Mass., Fitchburg Gas \& Elec. Light Co., 62.

114. Mass., Hudson Light \& Power Dep't, 229.

115. Union Elec. Light \& Power Co., 1918E P.U.R. 490, 511.

116. In re Caribou Water, Light \& Power Co., 121 Me. 426, 117 At1. 579 (1922). 
should bear the burden of future taxes imposed by the town, or whether the possibility of variable utility rates in and of itself frightened the court into rejecting the contract. ${ }^{117}$

The next proposal for tax escalation was made in 1933. This, too, failed of approval, although not so crushingly as its predecessor. ${ }^{118}$ There the matter rested for several years. Just how long, it is difficult to determine. The Public Utilities Reports series includes no cases involving tax escalation proposals between 1933 and 1941; but some of the presently-operative tax clauses are stated as applying to increases occurring after $1938,{ }^{119}$ so that one must assume there were cases in that period which were not reported. There is an alternate possibility, however. In some cases the regulatory commissions have allowed publication of tax clauses without objection, relying on their general supervisory powers to question the clauses at the time they become operative, if ever. Thus in Connecticut, "although certain tax adjustment clauses are on file they have not been and will not be applied without specific authorization of the [Public Utilities] Commission."120

This hypothesis might also help to explain the anomalous situation in Wyoming. One utility there has a tax clause in all electric rate schedules applicable within the state, providing for increases in rates to compensate for "any impost, assessment or charge imposed or levied by any governmental authority as a result of laws or ordinances enacted after May 1, 1948." 121 In 1956 the same company proposed a similar clause in gas schedules. The state's Public Service Commission disapproved.

"Inclusions of such clauses in utility tariffs are a relatively new innovation resulting from the fact that governmental units, primarily municipalities, in their search for new revenue sources have been turning recently to such taxes on utilities. To date we have not had much experience with such,taxes and pass-on clauses and we are not presently convinced that such a clause in a tariff is either desirable or adequate to achieve its purpose. Before allowing such a clause we feel that we should have more time to observe the effects of such taxes and assessments in Wyoming, and also to observe the experiences of other regulatory bodies with similar clauses." 122

117. The Maine Public Utilities Commission adhered to the latter view. Portland Gas Light Co., 69 P.U.R. (n.s.) 154 (1947); see Castine Water Co., 47 P.U.R. (n.s.) 522 (Me. 1947).

118. Newport Water Corp., 1933E P.U.R. 1, 24 (R.I.) (quoted at note 5 supra). 119. E.g., Kan., Kansas Gas \& Elec. Co., 63 ; cf. Lawrence Gas \& Elec. Co., 38 P.U.R. (n.s.) 89 (Mass. 1941) (proposing substitute tax clause for one then in effect). 120. Letter from Daniel E. Ahearne, Ass't Sec'y to author, June 21, 1956.

121. Wyo., Montana-Dakota Util. Co., 26. The date varies from one schedule to another, but in no case is it later than July 1, 1949.

122. Montana-Dakota Util. Co., 13 P.U.R.3d 523, 533 (1956). In October 1956 the Commission permitted filing of the tax clause in Montana-Dakota Util. Co. tariff No. 1-2, original sheet No. 12-14, Montana-Dakota Util. Co., 15 P.U.R.3d 246 (1956). 
Tax clauses are as varied as fuel clauses in form and applicability. They are found in thirty-four states, compared to forty-four with fuel clauses but including each of the four states without fuel clauses. They apply to all classes of consumers in twenty-five of these states, although in two states the clauses apply to all consumers in limited areas only. They are applied in sixteen states to less than all classes of consumers in a given area.

The forms of these clauses, though infinitely varied, may be grouped into three or four categories. The most prevalent provides for escalation in proportion to "any taxes or governmental impositions which are assessed on the basis of gross revenues of the utility and/or the price or revenue from the electric energy or service sold and/or the volume of energy generated or purchased for sale and/or sold hereunder." ${ }^{23}$ Basically, such a clause is designed to cover any taxes imposed on or measured by units of energy or price. These are obviously the easiest taxes to prorate.

The next group of tax clauses are those designed to recoup local taxes, imposed by local authorities or by the state legislature under laws of local application. These provisions are readily justifiable on the ground that the consumers in town $A$ cannot be expected to contribute toward the cost of a tax levied by town $B$ on a utility serving both localities. Such clauses may provide:

"Bills will be increased within the limits of any municipality which levies special taxes, license and franchise fees, or rentals against the utility's property, operation, or production and/or sale of energy to compensate for such taxes, fees, or rentals." 124

In some cases tax clauses are published which refer to "any governmental authority," but which are intended to operate only with respect to taxes of local applicability. ${ }^{125}$

A few clauses refer to franchise taxes only, such as the Washington utility schedule which provides for increases "to compensate for any new Federal, State, county, or municipal tax . . . upon or in respect of the right of the utility to operate or do business within the jurisdiction imposing the tax." 126

123. Ariz., Arizona Pub. Serv. Co., 2. Some utilities include transmission as well as generation, purchase and sale, and also taxes on meters or customers. Colo., Colorado Cent. Power Co., 6.

124. Fla., Gulf Power Co., 39; see also Ill., Commonwealth Edison Co., 74; Wash., Washington Water Power Co., 26.

125. This has been said to be true of the clause in Del., Delaware Power \& Light Co., 1 (telephone information from L. R. Leslie, Vice-President, Jan. 23, 1957).

126. Wash., Modern Elec. Water Co., 55; cf. N.Y., Niagara Mohawk Power Corp., 96 (taxes on use of Niagara River water). 
There are clauses providing compensation for all taxes other than income or ad valorem taxes. ${ }^{127}$ And there are provisions covering all taxes "imposed on the utility," 128 "any new form of tax," 129 "any new or additional taxes levied upon the company," 130 and similar blanket provisions. ${ }^{131}$

Finally, there is one tax clause which is completely unique, on two counts. First, it is the only tax clause which has an experience factor. In all the other clauses there is a base date; but if taxes increase above those in effect on that date, the clauses provide for immediate escalation. Second, this unique provision is more than a tax clause since it is pegged, not to a given tax level, but to a proportion of operating revenue. The clause provides: "Bills . . . are subject to an increase of $0.1 \%$ for each full $0.1 \%$ increase above $17.6 \%$ in the percentage ratio which taxes bear to operating revenues for, the 12 months preceding the customer's billing period." ${ }^{132}$ Under this clause, consumers could be surcharged even though the tax statutes, including the rates therein, remained unchanged. Consider, for example, the effect of increasing business (and increasing revenue) under a graduated corporate income tax.

Unfortunately, there is no published report involving the insertion of this clause in the rate schedules; and the office of the Oregon Public Utilities Commissioner, in reply to a general inquiry, made no reference to it. ${ }^{133}$ Such a clause has been the subject of only one reported case. The Lawrence Gas and Electric Company proposed in 1941 that such a clause (providing for recovery of all tax payments in excess of nineteen per cent of operating revenue) be substituted for the then-applicable provision for recovery of payments for new taxes. The Massachusetts Department of Public Utilities rejected this proposal, although recognizing that tax increases were imminent, because it would enable the utility to recover taxes "without striving to meet them either by effecting operating economies or increasing revenues by increased sales. It removes the incentive which the company otherwise has to seek tax reductions." 134

127. E.g., Kan., Kansas Gas \& Elec. Co., 54.

128. Ariz., Citizens Util. Co., 45.

129. Colo., Walsenburg Util., 131.

130. Idaho, Bunker Hill \& Sullivan Mining \& Concentrating Co., 1. Since preparation of this material operation of the service to which this schedule applied has been assumed by Washington Water Power Co., whose tax clause is similar to that at note 124 supra.

131. Me., Maine Pub. Serv. Co., 38; Mont., Montana Power Co., 7.

132. Ore., California-Pacific Util. Co., 9.

133. Letter from David Don, Chief Engineer, to author, June 29, 1956.

134. Lawrence Gas \& Elec. Co., 38 P.U.R. (n.s.) 89, 90 (1941). 
This is as much analysis as any commission has given to tax clauses. The majority of the opinions either accept or reject them rather summarily. Michigan approved such a clause in a short-form opinion; ${ }^{135}$ Massachusetts rejected one on stare decisis grounds alone; ${ }^{136}$ Pennsylvania held this was "not the only or best means by which a public utility may be protected against increases in operating and tax costs, which result from extraordinary or emergency conditions," although no alternate means was suggested. ${ }^{137}$ The Federal Power Commission rejected such a clause without consideration on the merits, because it might have violated an outstanding maximum rate order; ${ }^{138}$ a few months later it approved a similar clause without discussion. ${ }^{139}$

Tax clauses face every argument advanced in opposition to fuel clauses, and one other. Such clauses, it is said, remove the incentive to seek tax reductions. ${ }^{140}$ This is not true in all cases, inasmuch as the tax clauses relieve the utility of only the tax itself, and not the cost of collecting it. Furthermore, the regulatory agencies which assert this do not consider the question of whether it is advantageous to the political community to have public utilities (or any industry) support tax-reduction campaigns. That question, of course, is beyond the scope of this discussion.

Jurisdictions such as Massachusetts ${ }^{141}$ and Utah ${ }^{142}$ which have allowed fuel clauses but not tax clauses, can reconcile their rulings only on the basis of comparative percentages of total operating costs. Logically, if one element of cost may legally be escalated, all costs may be treated similarly. The Utah Public Service Commission acknowledged this when it said:

"We can see no greater reason why any automatic adjustment in the company's rate should be made to compensate for changes in the price of coal than automatic adjustments to compensate for changes in the cost of labor, material, and taxes." 143

The Maine Public Utilities Commission agreed.

"If this [fuel escalator] proposal is sound in principle, it would be equally sound for this or some other utility to make use

135. Consumers Power Co., 39 P.U.R. (n.s.) 130 (1941).

136. Buzzards Bay Gas Co., 79 P.U.R. (n.s.) 22 (1949).

137. Edison Light \& Power Co., 44 P.U.R. (n.s.) 275, 276 (1942).

138. Tennessee Gas \& Transmission Co., 69 P.U.R. (n.s.) 48 (1947).

139. Interstate Natural Gas Co., 70 P.U.R. (n.s.) 129 (1947).

140. Lawrence Gas \& Elec. Co., 38 P.U.R (n.s.) 89 (Mass. 1941).

141. Worcester Gas Light Co., 9 P.U.R.3d 152 (1955).

142. Compare Southern Utah Power Co., 77 P.U.R. (n.s.) 109 (1949), with Utah Power \& Light Co., 95 P.U.R. (n.s.) 390, 399 (1952) (dictum).

143. Utah Power \& Light Co., supra note 142. 
of a similar clause with reference to labor costs, so that the rates would fluctuate in direct proportion with wage adjustments. " 144

\section{Escalation of Other Costs}

If the principle of escalation is established, and if (as these two commissions declare) it applies equally to all elements of cost, why is it not used with reference to labor costs, or even to operating expenses generally? The answer, if there is one, is regulatory conservatism or inertia. But it is submitted that such costs are presently subject to escalation, and that the commissioners in Maine and Utah spoke truer than they knew.

The Federal Power Commission lists escalator clauses in electric rate schedules in ten states which are governed by costs other than fuel or taxes. Three of these will be noticed only in passing. The Omaha Public Power District provides for escalation based on total production costs; ${ }^{145}$ Dallas Power and Light Company and Minnesota Power and Light Company vary their rates in accordance with increases or decreases in the United States Department of Labor "All Commodities Index." 140 None of these utilities is subject to rate regulation, however, so the three clauses are of statistical interest only.

Of the seven remaining states, the most extreme escalators appear in Florida. Two clauses in use there provide for a percentage increase in utility bills for each increment of increase in the United States Department of Labor index of commodity prices other than farm products (or the Department of Commerce composite construction index, depending on the utility publishing the clause). ${ }^{147}$

Ohio boasts a clause providing for escalation in proportion to "cost of labor including related costs caused by changes from existing . . . wage or salary rates and benefits, at a rate of $0.25 \%$ per $\$ 100,000$ of change in taxes and/or cost of labor allocated" to electric operations. ${ }^{148}$ No experience factor is shown in the clause. It is applicable in less than all the territory served by the utility, the area of applicability having been reduced during $1956 ;^{149}$ it applies to all classes of consumers in the area where it is in effect.

144. Portland Gas Light Co., 69 P.U.R. (n.s.) 154, 157 (1947).

145. Neb., Omaha Pub. Power Dist., 135.

146. Tex., Dallas Power \& Light Co. (subject to approval by the Dallas City Council) ; Minn., Minnesota Co., 7.

147. Fla., Florida Power \& Light Co., 1; Fla., Florida Power Corp., 16.

148. Ohio, Cincinnati Gas \& Elec. Co., 2 (issued March 31, 1956).

149. Compare Ohio, Cincinnati Gas \& Elec. Co., 1 (issued Sept. 1, 1956), with Ohio, Cincinnati Gas \& Elec. Co., 2 (issued March 31, 1956). 
Five other states have escalator clauses so constructed as to include in the basis some portion of labor costs. Thus in Arizona the escalation is based on "'average cost of power' . . . determined by dividing the sum of the total Yuma area electric department operating expenses, excluding general expenses, overheads and fixed charges, by the total kwh sold in the Yuma area." 150 Kansas Gas and Electric Company's fuel clause includes in cost of fuel the "net cost of removing refuse, as shown by utility's books." 151 A Missouri utility adjusts rates on the basis of power cost, including "all production expenses (including depreciation of all generating plants) incident to generation of electric power and energy by utility." 152 Two utilities in West Virginia have clauses providing in identical terms for escalation on the basis of production costs. ${ }^{153}$ All these clauses are applied to large consumers only; experience factors include one month and twelve months, with no specific period expressed in the Arizona clause.

Schedules of Southern Colorado Power Company include the following "Tax, Wage, Commodity Price Clause":

"Utility reserves the right to increase the rates by not more than $10 \%$ for that period during which its operating expenses are increased beyond those incurred during 1941 by any cause beyond utility's control, such as the effect of war, inflation, labor costs, imposition and collection of new or greater taxes, license fees or government regulation, when such increases are over and above the normal increase due to growth of utility's business.

"The basic percentages of operating costs (Exclusive of fuel, excise taxes, and general officers' and executives' salaries) to gross revenues from the sale of electric energy will be as follows for each quarter calendar year:

$$
\begin{array}{ll}
\text { Jan., Feb., Mar. } & 45.9 \% \\
\text { Apr., May, June } & 46.5 \% \\
\text { July, Aug., Sept. } & 45.0 \% \\
\text { Oct., Nov., Dec. } & 44.5 \%
\end{array}
$$

Utility may increase rates to the extent that corresponding current quarterly percentages exceed these basic quarterly percentages." 154

While gas rate schedules have not been examined as thoroughly as electric schedules, fuel and tax clauses are understood to be approximately as widely used in the former as in the latter. Of special interest, however, is a "gas production cost adjustment" applicable in

150. Ariz., Arizona Pub. Serv. Co., 16.

151. Kan., Kansas Gas \& Elec. Co., 55.

152. Mo., City Util. of Springfield, 341.

153. W. Va., Monongahela Power Co., 13; W. Va., City of Philippi, 76.

154. Colo., Southern Colo. Power Co., 45. 
Delaware, computation of which includes labor and overhead costs allocable to production rather than transmission or administration. The clause embodies a twelve-month experience factor. ${ }^{155}$

This group of "production cost escalator clauses," as they may be called, are the logical culmination of the escalator principle. They are less understandable to the small consumer, perhaps, than the simple fuel clause; but, as has been shown, this is no longer a viable argument. Other objections to escalation apply to production-cost clauses with the same force as to fuel clauses, except the argument that they allow rate increases without consideration of all pertinent factors. ${ }^{156}$ This argument loses, as to production-cost clauses, much of the force it had as to fuel clauses, because the production-cost clause compensates for possible counter-fluctuations in prices other than fuel. Thus at the present time production-cost clauses should receive more favorable treatment than clauses pegged to less than all elements of production cost.

\section{Administrative Problems}

It has been observed that most fuel clauses, and all of the production-cost clauses, contain an experience factor; most tax clauses, being related to taxes assessed on a per-dollar or per-kilowatt-hour basis, lack this element. Where the experience factor is involved, the rate adjustments normally take effect on bills rendered during the second month after the price change which they reflect. Thus, if the experience period ends on December 31, the rates will reflect that experience beginning with February billings. The interval is allowed for two purposes: computation of the adjustment, and its publication.

A delay of this length maintains the legal principle which prohibits retroactive rate changes. During the intervening month the customer will receive notice of the proposed rate, and has the privilege of either filing a complaint with the regulatory agency or terminating his use of the service, before he uses any unit of service for which he will be billed at the new rate.

There are, however, clauses referring to a lesser time lag than the case suggested. Many clauses refer to the preceding month, rather than the second preceding month as suggested here. These would appear to conflict with the principle that bars retroactive rate changes; in practice many of them are applied as outlined above, so that the

155. Telephone information from L. R. Leslie, Delaware Power \& Light Co., Jan. 23, 1957.

156. See text at notes 25-28 supra. 
conflict is avoided. ${ }^{157}$ In a few cases they are not so applied; rather, the clauses state that the adjustment will appear as a debit or credit on the following month's bill. ${ }^{158}$ This clearly operates as a retroactive rate change; yet there is in the reports no recognition of this problem, and apparently no justification of the practice by special statute or otherwise.

There are precedents for this. The United States Supreme Court has recognized that rate changes may be made retroactive to the time of filing of a request for increase, ${ }^{159}$ and Connecticut has declared retroactivity to be permissible with specific approval of the Public Utilities Commission. ${ }^{160}$ The Federal Power Commission has also permitted retroactivity in utility rates, where they are changed in accordance with an escalator clause made part of the tariff prior to the effective date of the retroactive change. ${ }^{161}$ Wyoming has approved retroactivity even where no escalator had previously been filed, where no other equitable apportionment of costs as between consumers was possible. ${ }^{162}$ Actually there is no real objection to retroactivity at least where the consumer knew prior to the effective date that the rates would be increased on the happening of a defined event. This presumably is the theory on which the short-experience fuel clauses referred to above $^{163}$ have been approved.

A few statutes, however, require that a public hearing be held before any increase in rates is approved. The Illinois Public Utilities Commission, interpreting a statutory provision that "no public utility shall increase any rate. . . under any circumstances whatsoever, except upon a showing before the Commission and a finding by the Commission that such increase is justified," 184 held:

"This seems to contemplate a formal showing which would justify any increase allowed, and certainly does not contemplate the allowance of an increase of rates predicated on the bare statement of the public utility involved that it has paid a certain amount for coal." 165

157. Letter from E. M. Nicholson, Interstate Power Co., to author, Jan. 24, 1957.

158. Ark., Oklahoma Gas \& Elec. Co., 32 (large light and power schedule); Mo., Empire Dist. Elec. Co., 32-33 (lead and zinc mining and milling schedules). $C f$. a schedule providing that the cost of fuel shall be the average of fuel "on hand on the first of the succeeding month." Ohio, Toledo Edison Co., 225.

159. TWA v. CAB, 336 U.S. 601 (1949) ; United States v. New York Cent. R.R.,

279 U.S. 73 (1929) (both cases involving mail pay).

160. Guilford-Chester Water Co., 1928C P.U.R. 545.

161. Gulf States Util. Co., 78 P.U.R. (n.s.) 21 (1949).

162. See Montana-Dakota Util. Co., 15 P.U.R.3d 246 (1956), and letter from H. N. Elvig, Montana-Dakota Util. Co., to author, Jan. 28, 1957.

163. See text at note 158 supra.

164. Itr. Stat. ANN. $\$ 8686(51)$ (Callaghan 1916) (subsequently repealed).

165. Rockford Elec. Co., 1917F P.U.R. 196, 201. But cf. Alton Gas \& Elec. Co., 1917F P.U.R. 12 (I11.). 
The Indiana Public Service Commission reached the same conclusion, although the statute involved did not specifically require a hearing.

"[I]t would appear that the Commission is without power to confer authority for increasing rates contingent upon some future happening, and that it would be necessary for the Commission to determine whether or not the price of coal had increased or decreased. Therefore it makes little difference whether the coal clauses are placed in the tariff or not, for the reason that it would be necessary for the Commission, either on petition of the consumer or the utility, to ascertain the prevailing price of coal before allowing an increase or reduction in rates, on the theory that no increase in rates can be allowed without a public hearing." 106

There is no authority to the contrary, and it may be that the problem raised by this type of statute can be solved only by obtaining the repeal of the mandatory hearing provision. However, it is significant at this point to note again that, notwithstanding such statutes, every state has presently in effect one or more escalator clauses.

A more complex problem involves the requirement that utility rates be filed for public inspection, usually thirty days before they become effective. Whether, or to what extent, escalation violates the letter or the spirit of these requirements has plagued the Commissions from the beginning. The Pennsylvania Public Service Commission, in an early case involving a street lighting contract, took the conservative view.

"[An escalator] provision is not in and of itself objectionable, but it is desirable to point out that it does not prescribe a rate or constitute a tariff schedule; it merely, and perhaps quite properly, reserves to the parties to the contract the right to vary the specified rates dependent upon future changed conditions. It is expedient, therefore, to direct attention that, in order to vary the rates as contemplated in the provision referred to from those definitely fixed in the contract, the light company must from time to time, as changes are to be made, post, publish, and file, in accordance with the requirements of the Public Service Company Law, tariffs or amended tariffs, and therein definitely fix the rates to be applied.

"The Public Service Commission cannot, of course, predetermine the reasonableness or unreasonableness of such anticipated changes. . . ."167

The Illinois Public Utilities Commission at about the same time rejected an escalator clause completely, holding that it was in conflict with the statute.

166. Indiana Serv. Corp., 1930B P.U.R. 278, 281, construing INd. ANN. STAT. § 54-317 (Burns 1951).

167. Mercer County Light, Heat \& Power Co., 1919A P.U.R. 907. 
"[T] he law specifically provides that the utilities shall file schedules showing rates which are in force at the time for any product or commodity furnished, or to be furnished. It is the obvious intent of the Public Utilities Commission Law to provide that every public utility . . . shall have on file with the Commission a complete schedule of rates from which its bills for service may be accurately and definitely determined. . . " 108

A similar conclusion was reached in Maine. ${ }^{169}$

Other Commissions have taken a different position. They allow the escalator clause to be filed, but require that whenever rate increases occur as a result of the clause a new tariff or supplement be filed showing the new rates. In such cases, the Commission normally grants for the future the right to file such supplements on less than the statutory notice. For example, the California Public Utilities Commission conditioned its approval of a fuel clause on the

"requirement that the applicant shall file revised rates within fifteen days after a change in the price of fuel oil which would result in a change in the effective rates of the tariffs. Moreover, '. . . the new gas rates shall be effective beginning with the bill based on the first regular monthly meter reading for billing purposes which is taken on and after the thirtieth day following such change in the price of fuel oil. . . ."

thereby solving, at the same time, the requirement of tariff filing and. the problem of retroactive effect. ${ }^{170}$

New Jersey requires, in the case of gas distribution companies, the filing of a tariff supplement on thirty days' notice, specifying an effective date not less than seven days following the effective date of the cost increase on which it is based. ${ }^{171}$ In the case of electric companies, tariff supplements were not required, but the utility was required to file with the regulatory agency each month a verified statement showing the prices paid for fuel, including freight, the kilowatt hours generated, and other details of the fuel clause calculation. ${ }^{172}$

This is the intermediate solution. It has been adopted in Illinois, ${ }^{173}$ notwithstanding that jurisdiction's earlier holding that escalation was contrary to the filing requirements of the Illinois statute; ${ }^{174}$

168. Rockford Elec. Co., 1917F P.U.R. 196, 199 (in original).

169. Portland Gas Light Co., 69 P.U.R. (n.s.) 154 (1947).

170. Southern Cal. Gas Co., 99 P.U.R. (n.s.) 272, 287 (1952).

171. South Jersey Gas Co., 96 P.U.R. (n.s.) 71 (1952); see New Jersey Natural Gas Co., 6 P.U.R.3d 249, 263 (1954).

172. Atlantic County Elec. Co., 1918B P.U.R. 589, 592.

173. Public Serv. Co., 1924B P.U.R. 386.

174. Rockford Elec. Co., 1917F P.U.R. 196. This section of the statute remains unchanged. Compare ILL. STAT. ANN. \$ 8686(48) (Callaghan 1916), with ILL. ANN. STAT. c. $111 \%$, $\$ 33$ (Smith-Hurd 1954). 
it is also used in New York. ${ }^{175}$ It was approved in Oregon, when that state had tariff provisions similar to escalator clauses. ${ }^{176}$

Some Commissions go still farther, and require no filing at all when escalator clauses operate to increase rates. ${ }^{177}$ As the Wisconsin Public Service Commission stated: "The company now submits monthly reports which will provide the date $[$ sic] required to check its operation and which will allow the Commission to act promptly if changed conditions warrant." ${ }^{178}$ The same is true in Louisiana, ${ }^{179}$ Illinois, ${ }^{180}$ and Wyoming. ${ }^{18 \mathrm{I}}$ Commission orders approving escalation in Indiana, ${ }^{182}$ Massachusetts, ${ }^{183}$ Maryland, ${ }^{184}$ and New Mexico ${ }^{185}$ are silent as to any information which might be required, and presumably require none.

This final step is actually unnecessary. The utility must perform the calculation, and thus no substantial burden is involved in notifying the Commission of the result; the filing of such information, on the other hand, would be of great assistance to the Commission in supervising the rate level.

The regulatory agencies which have adopted either of the latter two procedures-i.e., any procedure not requiring the publication of increases by tariff supplement-have overcome the major apparent obstacle to a real remedy by escalation, which is tariff filing requirements. The legal method by which this has been accomplished (and it is a noteworthy accomplishment, eliminating the expense and delay of formal tariff publication and notice) cannot be better stated than in the words of Commissioner Catterall of the Virginia State Corporation Commission:

"That rate schedules are expected to contain such clauses is recognized by $\S 56-236$ of the Code of Virginia, which requires every public utility to file its rate schedules with the commission, and says:

“‘. . Every public utility shall file with, and as a part of, such schedules, copies of all rules and regulations that in any manner affect the rates charged or to be charged.'

175. Brooklyn Borough Gas Co., 100 P.U.R. (n.s.) 271 (1953).

176. McPherson v. Pacific Power \& Light Co., 207 Ore. 433, 456, 296 P.2d 932, 943 (1956).

177. Wisconsin Michigan Power Co., 76 P.U.R. (n.s.) 153, 155 (1948).

178. See text at notes 167,170 supra.

179. Letter from James E. Reed, Jr., Central La. Elec. Co., to author, Jan. 22, 1957.

180. Letter from E. M. Nicholson, Interstate Power Co., to author, Jan. 24, 1957.

181. Letter from L. Duane Walrafen, Black Hills Power \& Light Co., to author,

Feb. 5, 1957.

182. Southwestern Ind. Power Co. 71 P.U.R. (n.s.) 148 (1947).

183. Town of Westfield, 1919B P.U.R. 34.

184. Consolidated Gas, Elec. Light \& Power Co., 1919A P.U.R. 66.

185. Community Pub. Serv. Co., 93 P.U.R. (n.s.) 18 (1951). 
"The legislature has, by the language quoted, recognized that rate schedules consist not merely of lists of rates in dollars and cents, but that they customarily include provisions that will in various ways affect the rates charged at the time of filing or to be charged thereafter.

"The next section of the Code, $\S 56-237$, begins:

" No change shall be made in any schedule filed pursuant to the preceding section, including schedules of joint rates, except after thirty days' notice to the commission, and to the public. . .

"The thing that the statute says must be filed is not every change in the consumers' bills, but every change in the schedules that affects the computation of the bills. A charge that can be computed by a fixed mathematical formula is as firmly fixed as a charge that is stated in terms of money." 186

The Federal Power Commission, while accepting the principle of escalation, has not concurred in this last interpretation. It has ruled that increases occasioned by such clauses are subject to the thirty-day notice provisions of the statutes ${ }^{187}$ and also that they must be filed by tariff supplement. ${ }^{188}$ The Commission has, however, permitted such increases to take effect retroactively. ${ }^{189}$

In jurisdictions where tariff supplements are required, escalator increases are clearly subject to suspension; the increases may be suspended also where they are allowed to take effect without filing a supplement. The Massachusetts Department of Public Utilities has, in fact, suspended increases published in accordance with an escalator clause previously approved by the Department. This act of suspension was attacked on the ground that "approval of the department of the filing of the original clause established the rate and that the department had no power to suspend its application. . . ." The Department, of course, ruled that it had such power. ${ }^{180}$

But such power is rarely exercised. The Massachusetts Department, in the same breath with which it declared its power to suspend escalation, added:

186. Lynchburg Gas Co., 6 P.U.R.3d 33, additional opinion sub nom. Virginia Elec. \& Power Co., 7 P.U.R.3d 108 (1954), aff'd sub nom. Norfolk v. Virginia Elec. \& Power Co., 197 Va. 505, 90 S.E.2d 140 (1955) (quoting Commissioner Catterall with approval). F 1953).

187. Southwestern Gas \& Elec. Co., May 2, 1951, cited in P.U.R. Dig. 98 (Supp.

188. Gulf States Util. Co., 78 P.U.R. (n.s.) 21 (1949).

189. Ibid.

190. Worcester Gas Light Co., 9 P.U.R.3d 152 (1955); see also Virginia Elec. \& Power Co., 7 P.U.R.3d 108 (Va. 1954), aff'd sub nom. N'orfolk v. Virginia Elec. \& Power Co., 197 Va. 505, 90 S.E.2d 140 (1955). 
"We think it no more than appropriate, however, to state the policy of the department in this connection. Unless current figures filed as part of the notice of increase indicate net earnings larger than would be normally appropriate in the case of gas distributing companies, the department does not intend to invoke its powers of suspension and conduct a rate case in connection therewith." 101

Research discloses no case other than this one wherein escalator rates have been suspended; and inquiry directed to numerous utilities has failed to establish any such action by any regulatory agency.

\section{Statutory Provisions}

To what extent have statutory changes been necessary to legalize escalator clauses? With one exception the answer is "none." The exception is in cases where the regulatory statute required a hearing before rates were increased. ${ }^{192}$

Space does not permit reference to statutes of all the states; nor would such a broad examination be of any appreciable advantage. For convenience, this section will be limited to the statutes in those states where existing escalator clauses recognize costs other than fuel and taxes. These clauses have been previously discussed. ${ }^{193}$

In Minnesota, Nebraska and Texas the rates referred to are unregulated. Three of the states in question have statutory provisions authorizing utilities to

"establish a sliding scale of charges, and . . . enter into an arrangement for a fixed period for the automatic adjustment of charges for . . . service, in relation to the profit to be realized by such person. A schedule showing the scale of charges under such arrangement shall first be filed with the Commission and the schedule and each rate set out therein approved by it." 194

Such statutes were probably enacted to permit other rate-making methods than escalation, ${ }^{195}$ although they are broad enough in language to include authority for escalation, if such authority is necessary.

The Ohio regulatory code specifically states that it does not "prohibit a public utility from filing a schedule . . providing for . ( (B) A sliding scale of charges, including variations in rates

191. Worcester Gas Light Co., supra note 190.

192. See text at note 164 supra.

193. See text at notes $145-156$ supra.

194. Ariz. Rev. Stat. Ann. \& 40-368 (1956) ; Colo. Rev. Stat. ANN. §115-3-6 (1953); Mo. Ann. Stat. \$393.130(4) (1952).

195. Such as that adopted in Indiana Gen. Serv. Co., 1920A P.U.R. 489, 498 (Ind.); see WiLcH, CONDUCY OF THE, UTIITY RATE CASE 33 (1955). 
based upon stipulated variations in cost as provided in the schedule. . . ." 196

Florida has a very brief statute giving its Railroad and Public Utilities Commission general power over all rate matters, but no special authority exists for the publication of escalator clauses. ${ }^{197}$

The other three states in the group have regulatory laws patterned very closely (in some sections, verbatim) after the federal statutes. ${ }^{198}$ None of these laws contains any language similar to that quoted above as effective in Ohio.

Based on these eight states, representing all sections of the nation, the conclusion is warranted that escalation is possible without special statutory authority. The regulatory Commissions have plenary power over rates and tariffs, and can and do exercise that power, in the public interest, to establish rates which are designed to keep pace with a changing economy.

\section{CONCLUSION}

Every political jurisdiction in this country has escalator clauses in the published tariffs of its utilities, although some of the clauses are inoperative. Such provisions must be considered as departures from the intent of the regulatory laws, which indubitably contemplated tariffs setting forth rates in dollars and cents per physical unit. But they have clear advantages. The obvious disadvantage, of leaving the average consumer as ill informed of the exact method of calculating the rate he pays as if no tariff were filed initially, is far outweighed by the advantages of flexibility, efficiency, and economy of regulatory administration. This is particularly true since regulatory control has not been in the least diluted by this method of rate making.

Another asserted disadvantage is that escalation removes from utility management the incentive to use its bargaining power to keep costs of operations at a minimum. This actually does not occur in practice, because the delay between the payment of increased costs and the reflection of those costs in bills to customers would reduce profits as costs increase, and because in virtually ail cases, escalation provides less than complete compensation to the utility for cost increases. ${ }^{199}$

Caution on the part of utility officials, and inertia within the regulatory agencies, have probably both influenced the present limits

196. OhIo Rev. CoDE ANn. § 4905.31 (Anderson 1953). Similar provisions are found in N.Y. PUb. Serv. Law $\$ 65(4)$ and PA. Stat. ANn. tit. 66, §1147 (1941).

197. Fla. Stat. ANN. $\$ 366.06$ (Supp. 1956).

198. Det. Code AnN. tit. 26, $\$ \$ 127,151-57$ (1953) (Section 127 includes power to fix "special rates."); KAN. GEN. STAT. ANN. §§ 66-101 to 66-117 (1949); W. VA. CODE ANN. \$§ 2552-67 (1955).

199. See text and notes at notes 16,17 supra. 
of the escalator principle. Certainly there is no logical reason why some cost increases should have an automatic influence on utility rates while others have none. Escalation clauses involving all costs of production and transmission in a single formula are no more than extensions of the principle recognized in Alton Gas \& Elec. Co. ${ }^{200}$

Aside from caution and inertia, there is a political factor militating against escalation based on total costs. The customer of a regulated industry has always been an interested party, entitled as of right to a day in court even though he had no real understanding of the technical issues involved. Escalation based on total costs has the effect of making rates depend on facts presented to the administrative agency on an ex parte basis, with no opportunity for most customers to examine or dispute the facts so presented. Thus this proposition involves a limitation on the rights of the customers.

So runs the theory. In practice, these rights of the customers are rarely exercised except by associations, industries, or political agencies, because of the small amounts of money involved for individual customers and because of the complex and technical nature of the issues involved in rate proceedings. As to these litigants, their nature and organization place them in a position from which they are constantly informed of the utility's situation, and from which they can, therefore, police escalation clauses in spite of the ex parte nature of any changes in the rate calculation.

Since this is so, the now virtually universal acceptance of escalation based on certain cost elements should lead eventually to adoption of this procedure on a broadened scale. The results will be reduced costs of administration and litigation, greater correlation of utility rates with general economic trends, and greater stability for the regulated industry.

200. 1917F P.U.R. 12 (III.). 